\title{
ANALISIS UNIVARIAT DAN MULTIVARIAT CONTO SEDIMEN SUNGAI DALAM PENENTUAN POTENSI MINERALISASI LOGAM DI HALMAHERA BAGIAN TIMUR, PROVINSI MALUKU UTARA
}

\section{UNIVARIATE AND MULTIVARIATE ANALYSIS OF STREAM SEDIMENT SAMPLE FOR DETERMINATION OF METAL MINERALIZATION POTENTIAL IN THE EASTERN PART OF HALMAHERA, NORTH MALUKU}

\author{
Reza Mochammad Faisal', Irfan Budiaji Nugroho², dan Bambang Priadi² \\ ${ }^{1}$ Pusat Sumber Daya Mineral, Batubara dan Panas Bumi \\ ${ }^{2}$ Program Sarjana, Prodi Teknik Geologi, FITB-ITB \\ reza.faisal@esdm.go.id
}

\begin{abstract}
ABSTRAK
Penelitian geokimia dengan mengunakan metode analisis kandungan unsur dari conto endapan sungai aktif -80 mesh merupakan salah satu fase awal eksplorasi terutama untuk menemukan cebakan mineral logam. Halmahera bagian timur dengan tataan geologi yang kompleks dan berada dalam jalur metalogenik yang berpotensi membentuk cebakan logam, menghasilkan rona geokimia yang sangat bervariasi dan menarik. Data geokimia sedimen sungai aktif yang tertuang dalam bentuk peta sebaran unsur menyajikan informasi awal yang penting tentang indikasi mineralisasi untuk ditindaklanjuti ke tahap penelitian lebih rinci, khususnya mineralisasi nikel yang berasosiasi dengan litologi Komplek Ultrabasa.
\end{abstract}

Penafsiran data geokimia di wilayah penelitian dengan pendekatan analisis statistik univariat dan multivariat yang terdiri dari unsur $\mathrm{Cu}, \mathrm{Pb}, \mathrm{Zn}, \mathrm{Co}, \mathrm{Ni}, \mathrm{Mn}, \mathrm{Ag}, \mathrm{Fe}, \mathrm{Cr}$, dan $\mathrm{Au}$, proses pengayaan unsur geokimia di lingkungan permukaan diperlihatkan oleh asosiasi spasial Co, $\mathrm{Ni}, \mathrm{Fe}$ dan $\mathrm{Mn}$, yaitu pengayaan unsur disebabkan pengikatan kimiawi (scavenging) oleh oksida Fe dan Mn. Berdasarkan kekerabatan unsur atau hubungan antar unsur diperoleh dua kelompok unsur yaitu ikatan unsur $\mathrm{Cu}-\mathrm{Pb}-\mathrm{Zn}-\mathrm{Ag}-\mathrm{Cr}$ dan $\mathrm{Co}-\mathrm{Ni}-\mathrm{Mn}-\mathrm{Fe}-\mathrm{Au}$, akan tetapi tidak semua kelompok asosiasi unsur dapat dihubungkan dengan litologi di daerah penelitian.

Kata kunci: geokimia, Halmahera Timur, metalogenik, mineralisasi, univariat, multivariat

\section{ABSTRACT}

Geochemical research used the analysis method of -80 mesh of active stream sediment samples is one of the early phase exploration specially in finding out metallic mineral deposits. Easternpart of Halmahera with its complex geologic setting and a metallogenic region is being potential to form metallic deposits, which create some variation and interesting geochemical performances. The geochemistry of stream sediment data by means in the form of elements distribution maps represent the basic important information of mineralization indications, which enable for detail follow up research, specifically nickel mineralization associated with the Ultrabasa Complex lithology.

Interpretation of geochemical data in the study area with univariate and multivariate statistical analysis approaches consisting of elements of $\mathrm{Cu}, \mathrm{Pb}, \mathrm{Zn}, \mathrm{Co}, \mathrm{Ni}, \mathrm{Mn}, \mathrm{Ag}, \mathrm{Fe}, \mathrm{Cr}$, and $\mathrm{Au}$, the process of enrichment of geochemical elements in the surface environment is shown by the spatial association of $\mathrm{Co}, \mathrm{Ni}, \mathrm{Fe}$ and $\mathrm{Mn}$, namely the enrichment of elements due to chemical binding (scavenging) by $\mathrm{Fe}$ and Mn oxides. Based on the kindship of elements or relations 
between elements obtained two groups of elements, namely the bonding elements of $\mathrm{Cu}-\mathrm{Pb}$ $\mathrm{Zn}-\mathrm{Ag}-\mathrm{Cr}$ and $\mathrm{Co}-\mathrm{Ni}-\mathrm{Mn}-\mathrm{Fe}-\mathrm{Au}$, but not all groups of element associations can be related to the lithology that develops in the study area.

Keywords: geochemistry, East Halmahera, metallogenic, mineralization, univariate, multivariate

\section{PENDAHULUAN}

Kegiatan penyelidikan geokimia bersistem telah dilakukan oleh Pusat Sumber Daya Mineral, Batubara dan Panas Bumi di Pulau Sumatera, Pulau Kalimantan, Pulau Sulawesi dan Kepulauan Nusa Tenggara. Selain untuk mencari wilayah prospek mineralisasi logam, kegiatan tersebut dapat dimanfaatkan untuk menentukan sebaran aliran sungai yang dicemari oleh unsur tertentu.

Pada Tahun 2018 penyelidikan geokimia dilakukan di wilayah Kabupaten Halmahera Timur, Provinsi Maluku Utara yang diketahui merupakan daerah penambangan nikel laterit (Gambar 1).

Makalah ini akan membahas hasil pengolahan data conto sedimen sungai menggunakan analisis univariat, multivariat, data analisis mineralogi butir, analisis petrografi dan analisis mineragrafi hasil penyelidikan geokimia. Tujuannya untuk mengetahui sebaran potensi mineral logam, selain nikel dan logam ikutannya. Analisis conto sedimen sungai terdiri dari $\mathrm{Cu}, \mathrm{Pb}, \mathrm{Zn}, \mathrm{Co}, \mathrm{Ni}, \mathrm{Mn}, \mathrm{Ag}, \mathrm{Fe}, \mathrm{Cr}$, dan $\mathrm{Au}$.

\section{METODOLOGI}

Metoda penelitian dengan menggunakan perangkat lunak untuk mengolah data statistik analisis univariat dan analisis multivariat. Data yang diolah sebanyak 106 conto sedimen sungai aktif hasil penyelidikan geokimia regional Lembar Ternate (Gambar 1).

Dari data kandungan unsur yang telah diperoleh kemudian dilakukan pengolahan data secara statistik menggunakan metode analisis univariat dan analisis multivariat.
Pengolahan data tersebut dilakukan guna memperoleh gambaran tentang perilaku sebaran unsur, serta ringkasan statistik berikut histogramnya. Dari pengolahan tersebut didapatkan hasil nilai latar belakang dan anomali yang berikutnya digunakan untuk estimasi pembagian populasi unsur.

Analisis univariat menggunakan metode simpangan baku dan kurva probabilitas, bertujuan untuk menentukan nilai anomali dari tiap-tiap unsur yang diolah menjadi peta geokimia unsur.

Metode simpangan baku merupakan metode yang digunakan untuk membatasi nilai anomali dan nilai latar belakang dengan mencari nilai dari harga rata-rata dijumlahkan dengan dua kali nilai simpangan baku (Rose dkk., 1979). Metode ini dapat digunakan apabila populasi data memiliki sifat distribusi normal atau nilai simpangan baku yang lebih kecil dari nilai rata-rata.

Metode kurva probabilitas merupakan metode yang digunakan dalam penentuan harga ambang suatu unsur dengan cara membuat kurva probabilitas. Harga ambang yang didapat digunakan untuk memisahkan data menjadi populasi anomali dan populasi latar belakang. Metode ini dapat digunakan ketika populasi suatu data berjumlah lebih dari dua.

Analisis multivariat bertujuan untuk membagi unsur-unsur ke dalam beberapa kelompok asosiasi unsur dengan cara melihat hubungan kekerabatan antar unsur secara spasial. Metode yang digunakan pada analisis multivariat terdiri dari metode koefisien Pearson, persentil, dan pengelompokkan hierarki. 


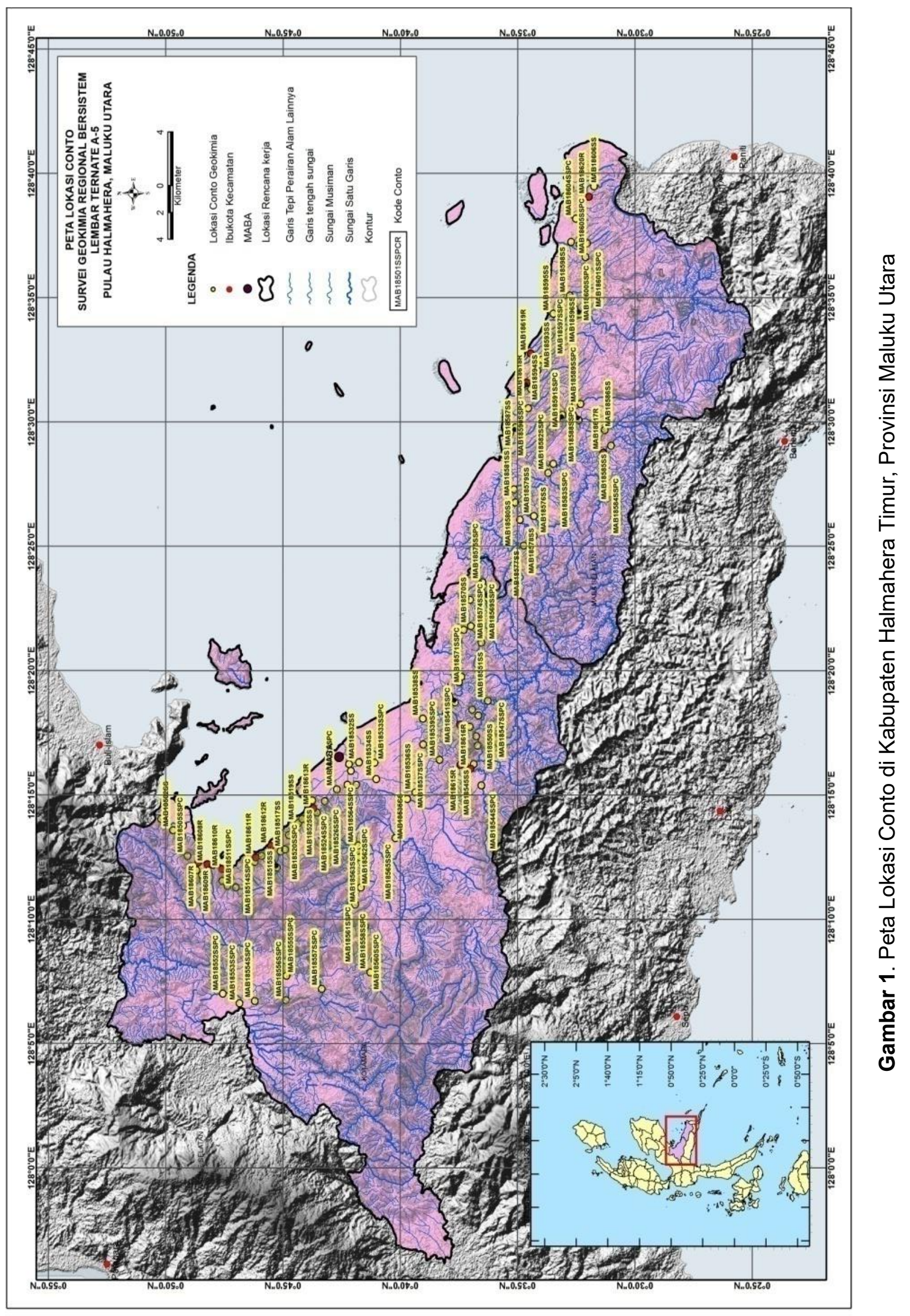


Metode koefisien Pearson bertujuan untuk menilai tingkat kekerabatan dari dua unsur atau lebih yang dinyatakan ke dalam koefisien Pearson (Ghazali dkk., 1986). Nilai koefisien berkisar dari -1 (korelasi negatif) hingga +1 (korelasi positif). Koefisien korelasi positif memiliki arti bahwa peningkatan nilai suatu unsur akan diikuti pula oleh peningkatan nilai unsur lain, begitu pula sebaliknya. Koefisien korelasi dengan kisaran nilai 0,5 sampai dengan 0,7 menunjukkan sifat asosiasi sedang dan koefisien dengan nilai lebih dari 0,7 menunjukkan asosiasi yang bersifat kuat (Swan dan Sandilands, 1995). Metode persentil dilakukan dengan melihat pola kandungan dari data unsur dengan nilai yang tinggi pada persentil tertentu (Surjadi, 1976). Pada metode ini harus ada unsur yang dijadikan sebagai acuan, umumnya dipakai unsur yang memiliki nilai konsentrasi tinggi dan bernilai ekonomis. Cara pengerjaannya dengan mengurutkan nilai konsentrasi tiap unsur dari mulai nilai tertinggi hingga nilai terendah, kemudian ditentukan persentil yang membatasi urutan tersebut dan dilihat pola kandungan dan hubungan antar unsur yang diolah. Nilai persentil berkisar dari 0 hingga 100.

Pengelompokan hierarki merupakan metode kluster yang mengelompokkan data secara berurutan berdasarkan kemiripan atau korelasinya (Karypis dkk., 1999). Pada metode ini setiap unsur dianggap sebagai satu variabel yang terpisah. Variabel-variabel tersebut kemudian digabungkan berdasarkan kemiripan secara berurutan hingga menjadi satu kelompok atau kluster besar. Penghitungan kemiripan atau jarak antar kluster dilakukan dengan metode Ward Linkage. Jarak antar kluster dihitung berdasarkan nilai error sum of square, sehingga tidak ada nilai yang saling menghilangkan. Hasil analisis digambarkan dengan dendogram (diagram pohon) untuk menunjukkan kluster hasil analisis pengelompokan hierarki.

\section{GEOLOGI REGIONAL}

Menurut Apandi dan Sudana, (1980) stratigrafi regional daerah penelitian sebagai berikut (Gambar 2):

Mandala Geologi Halmahera Timur sebagian besar terbentuk dari batuan dasar berupa batuan beku ultrabasa (Ub), yang diatasnya secara tidak selaras diendapkan batuan sedimen berumur Kapur (Kd) dan batuan sedimen berumur Paleosen hingga Eosen (Tped, Tpec, dan Tpel).

Struktur sinklin dan antiklin dijumpai pada Formasi Weda (Tmpw) yang berumur Miosen Tengah hingga Pilosen Awal. Sumbu lipatan berarah utara-selatan, timurlaut-baratdaya, dan baratlauttenggara. Struktur sesar terdiri dari sesar normal dan sesar naik, umumnya berarah utara-selatan dan baratlaut-tenggara.

Secara morfologi daerah penelitian memperlihatkan dua satuan morfologi yaitu berupa pegunungan berlereng curam, dan perbukitan landai. Morfologi pegunungan berlereng curam terdiri dari batuan ultrabasa (Komplek Batuan Ultrabasa), morfologi karst terbentuk oleh batugamping berumur Miosen hingga Pliosen (Formasi Tingteng) dan satuan konglomerat berumur Paleosen hingga Eosen, sedangkan morfologi perbukitan landai tersusun oleh batuan sedimen berumur Miosen hingga Pliosen (Formasi Weda) serta endapan aluvial berumur Resen. 




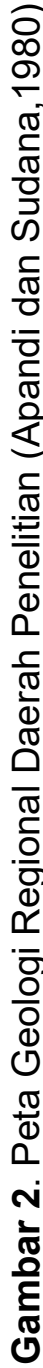




\section{HASIL DAN ANALISIS}

Kondisi geologi daerah penelitian didominasi oleh batuan serpentinit yang termasuk ke dalam Komplek Batuan Ultrabasa berumur Pra-Kapur. Analisis petrografi dari singkapan serpentinit pada titik MAB18610R di sekitar cabang Sungai Ake Fai, menunjukkan tekstur kenoblastik, berukuran halus hingga $0,31 \mathrm{~mm}$, disusun oleh mineral olivin, serpentin, muskovit, rutil, dan opak/oksida besi (Gambar 3).

Hasil analisis mineragrafi conto dari lokasi MAB18612R yang terletak di sekitar cabang Sungai Ake Fai, teridentifikasi kromit, kovelit, dan pirit. Kromit, berwarna abu-abu sampai abu-abu kecoklatan, berukuran sangat halus $(<0,05 \mathrm{~mm})$ hingga halus $( \pm 0,41 \mathrm{~mm})$, bentuk anhedral, bersifat isotrop, biasanya memiliki refleksi dalam merah-coklat, tampak retak-retak dan berlubang-lubang, dan tersebar tidak merata dalam massa batuan. Pirit, berwarna putih kekuningan, berukuran sangat halus $(<0,05 \mathrm{~mm})$ hingga halus $( \pm$ $0,13 \mathrm{~mm}$ ), bentuk anhedral, bersifat anisotrop lemah atau isotrop, tumbuh bersama magnetit mengisi retakan-retakan batuan, dan tersebar tidak merata/sangat jarang pada massa batuan. Kovelit, berwarna biru, berukuran sangat halus (< 0,05 mm), anhedral, mempunyai bireflectance, mempunyai sifat anisotrop kuat dengan warna coklat kemerahan, dan tersebar tidak merata/sangat jarang pada massa batuan (Gambar 4).



Gambar 3. Analisis Petrografi Conto Batuan MAB18610R

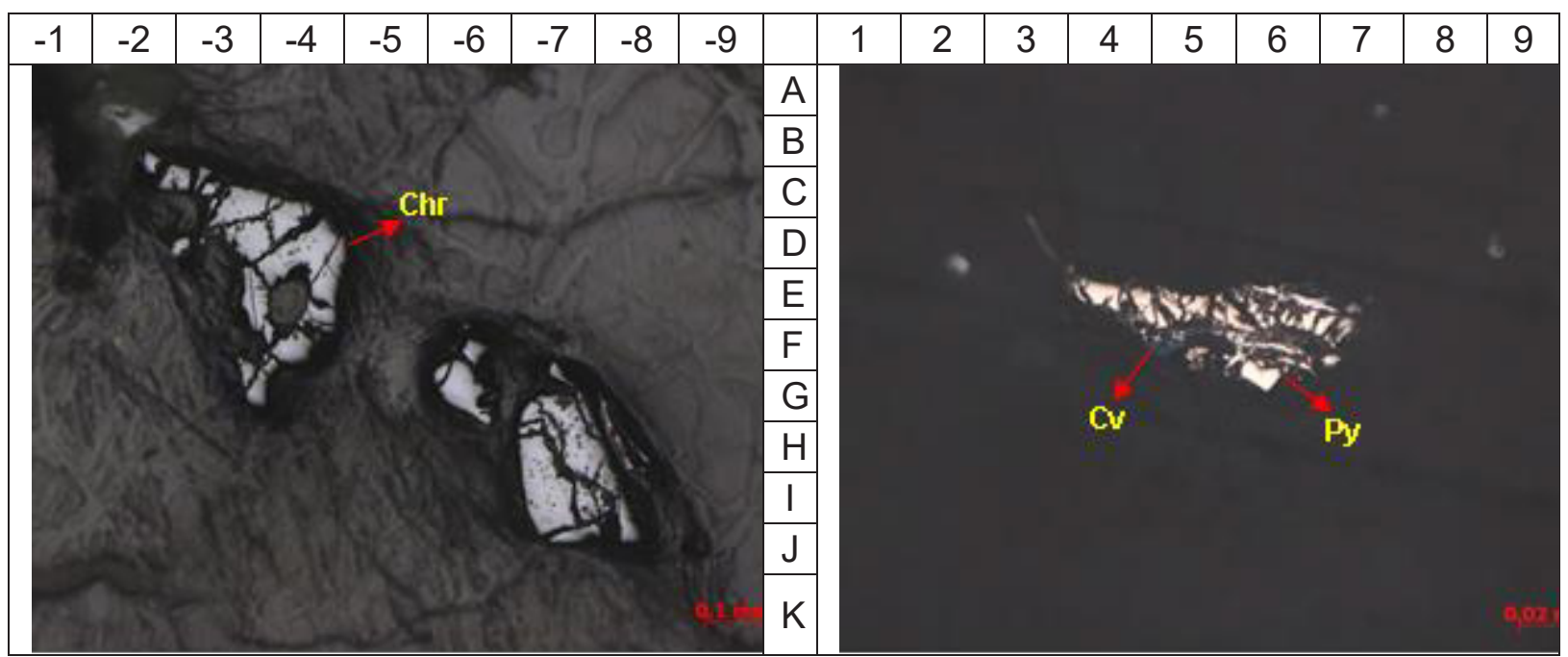

Gambar 4. Analisis Mineragrafi Conto Batuan MAB18612R 
Hasil analisis mineralogi butir menunjukkan mineral pirit dan garnet yang dapat mengindikasikan keberadaan mineralisasi, diantaranya yaitu porfiri dan/atau skarn (Gambar 5).

Berdasarkan analisis statistik univariat dari sepuluh unsur logam yang diteliti, dibuat ringkasan statistik geokimia endapan sungai aktif (Tabel 1 dan Tabel 2), untuk membandingkan kesamaan ciri geokimia dan kondisi geologi dengan cara pemodelan sistem informasi geografis dan statistik. Penentuan kelas geokimia untuk mendapatkan daerah peninggian nilai kandungan unsur sebagai indikasi populasi anomali dilakukan dengan metode simpangan baku dan kurva probabilistik (Rose dkk., 1979).
Metode simpangan baku yang digunakan untuk membatasi nilai anomali dan nilai latar belakang dengan mencari nilai dari harga rata-rata dijumlahkan dengan dua kali nilai simpangan baku (Rose dkk., 1979).

Metode ini dapat digunakan apabila populasi data memiliki sifat distribusi normal atau nilai simpangan baku yang lebih kecil dari nilai rata-rata. Metode kurva probabilitas digunakan dalam penentuan harga ambang suatu unsur dengan cara membuat kurva probabilitas. Harga ambang yang didapat digunakan untuk memisahkan data menjadi populasi anomali dan populasi latar belakang. Metode ini dapat digunakan ketika populasi suatu data berjumlah lebih dari dua.



Gambar 5. Analisis Mineralogi Butir Conto Konsentrat Dulang

Tabel 1. Ringkasan Statistik Geokimia Conto Endapan Sungai Aktif

\begin{tabular}{|c|c|c|c|c|c|c|c|}
\hline \multirow[b]{2}{*}{ Unsur } & \multirow[b]{2}{*}{$\begin{array}{l}\text { Rata-Rata } \\
\text { (ppm) }\end{array}$} & \multirow[b]{2}{*}{$\begin{array}{c}\text { Jumlah } \\
\text { Conto }\end{array}$} & \multirow[b]{2}{*}{$\begin{array}{l}\text { Maks } \\
\text { (ppm) }\end{array}$} & \multirow[b]{2}{*}{$\underset{(p p m)}{\operatorname{Min}}$} & \multicolumn{2}{|c|}{ Kadar Rata-rata Unsur } & \multirow[b]{2}{*}{$\begin{array}{c}\text { Anomali } \\
\text { (ppm) }\end{array}$} \\
\hline & & & & & $\begin{array}{l}\text { Kerak Bumi }{ }^{1} \\
(p p m)\end{array}$ & $\begin{array}{c}\text { Halmahera } \\
\text { Tengah }^{2}(\mathrm{ppm})\end{array}$ & \\
\hline $\mathrm{Cu}$ & 25 & 106 & 47 & 4 & 70 & 31 & 30 \\
\hline $\mathrm{Pb}$ & 15 & 106 & 90 & 0 & 16 & 45 & 27 \\
\hline $\mathrm{Zn}$ & 76 & 106 & 142 & 7 & 132 & 115 & 127 \\
\hline Co & 141 & 106 & 793 & 22 & 23 & 95 & 407 \\
\hline $\mathrm{Ni}$ & 1.531 & 106 & 7.254 & 127 & 80 & 1.289 & 3.388 \\
\hline $\mathrm{Mn}$ & 1.415 & 106 & 4.471 & 70 & 1.000 & 1.651 & 3.249 \\
\hline $\mathrm{Ag}$ & 1,7 & 106 & 3,5 & 0,1 & 0,1 & 3,1 & 2,8 \\
\hline $\mathrm{Fe}$ & 88.600 & 106 & 236.800 & 1.900 & 50.000 & 102.300 & 183.200 \\
\hline $\mathrm{Cr}$ & 1.920 & 106 & 4.663 & 114 & 200 & 746 & 3.851 \\
\hline$A u^{*}$ & 9 & 106 & 35 & 0 & 5 & 2 & 26 \\
\hline
\end{tabular}




\section{MAKALAH ILMIAH}

Tabel 2. Ringkasan Kelas Interval Conto Endapan Sungai Aktif

\begin{tabular}{cccc}
\hline \multirow{2}{*}{ Unsur } & \multicolumn{3}{c}{ Kelas Interval } \\
\cline { 2 - 4 } & $\begin{array}{c}\mathbf{1} \\
\text { (Anomali - Maks) }\end{array}$ & $\begin{array}{c}\mathbf{2} \\
\text { (Rerata - Anomali) }\end{array}$ & $\begin{array}{c}\mathbf{3} \\
\text { (Min - Rerata) }\end{array}$ \\
\hline $\mathrm{Cu}$ & $30-47$ & $25-30$ & $<25$ \\
\hline $\mathrm{Pb}$ & $27-90$ & $15-27$ & $<15$ \\
\hline $\mathrm{Zn}$ & $127-142$ & $76-127$ & $<76$ \\
\hline $\mathrm{Co}$ & $407-793$ & $141-407$ & $<141$ \\
\hline $\mathrm{Ni}$ & $3.388-7.254$ & $1.531-3.388$ & $<1.531$ \\
\hline $\mathrm{Mn}$ & $3.249-4.471$ & $1.415-3.249$ & $<1.415$ \\
\hline $\mathrm{Ag}$ & $2,8-3,5$ & $1,7-2,8$ & $<1,7$ \\
\hline $\mathrm{Fe}$ & $183.200-236.800$ & $88.600-183.200$ & $<88.600$ \\
\hline $\mathrm{Cr}$ & $3.851-4.663$ & $1.920-3.851$ & $<1.920$ \\
\hline $\mathrm{Au}$ & $26-35$ & $9-26$ & $<9$
\end{tabular}

\section{ANALISIS UNIVARIAT}

Hasil analisis univariat atas sepuluh unsur terpilih dapat dijelaskan sebagai berikut:

Tembaga (Cu). Unsur $\mathrm{Cu}$ memiliki nilai kandungan dengan rentang 4 ppm sampai dengan $47 \mathrm{ppm}$, didapati bahwa sebaran unsur $\mathrm{Cu}$ memiliki populasi unsur tertinggi di daerah penelitian dengan harga ambang bernilai 30 ppm (Gambar 6). Terdapat dua titik lokasi dengan kandungan unsur $\mathrm{Cu}$ tertinggi sebesar $47 \mathrm{ppm}$ yaitu titik MAB18552SS di cabang Sungai Ake Sangaji dan MAB18561SS di cabang Sungai Balipopo sehingga anomali $\mathrm{Cu}$ di wilayah penelitian kurang berkembang. Populasi sebaran unsur $\mathrm{Cu}$ tersebar pada Komplek Batuan Ultrabasa, Formasi Weda, dan Formasi Tingteng. Litologi yang dapat ditemukan di sekitar anomali unsur $\mathrm{Cu}$ yaitu berupa serpentinit, konglomerat, batupasir, dan batugamping. Sebaran unsur $\mathrm{Cu}$ diinterpretasikan terbentuk akibat mineralisasi epitermal dan/atau porfiri yang dikontrol oleh struktur berumur Pliosen hingga Pleistosen Tengah.

Timbal (Pb). Unsur $\mathrm{Pb}$ memiliki nilai kandungan dengan rentang $1 \mathrm{ppm}$ sampai dengan 90 ppm, didapatkan unsur $\mathrm{Pb}$ memiliki populasi anomali dengan harga ambang bernilai 27 ppm. Kandungan unsur $\mathrm{Pb}$ tertinggi terdapat pada titik lokasi MAB18583SS di cabang Sungai Ake Mlop (Gambar 7). Populasi anomali unsur $\mathrm{Pb}$ tersebar pada Komplek Batuan Ultrabasa,
Formasi Weda, dan Formasi Tingteng. Litologi yang ditemukan di sekitar anomali unsur $\mathrm{Pb}$ yaitu batuan serpentinit, konglomerat, batupasir, dan batugamping. Anomali unsur $\mathrm{Pb}$ diinterpretasikan terbentuk akibat mineralisasi epitermal dan/atau porfiri yang dikontrol oleh struktur berumur Pliosen hingga Pleistosen Tengah.

Seng (Zn). Unsur $\mathrm{Zn}$ memiliki nilai kandungan dengan rentang 7 ppm sampai dengan 142 ppm, didapatkan sebaran unsur $\mathrm{Zn}$ memiliki populasi unsur tertinggi di daerah penelitian dengan harga ambang bernilai 93 ppm dan 127 ppm. Terdapat dua titik lokasi dengan kandungan unsur $\mathrm{Zn}$ tertinggi sebesar 137 ppm dan 142 ppm yaitu titik MAB18564SS di cabang Sungai Ake Po dan MAB18597SS di cabang Sungai Ake Genyam (Gambar 8).

Populasi anomali unsur $\mathrm{Zn}$ tersebar pada Komplek Batuan Ultrabasa dan Formasi Tingteng. Litologi yang dapat ditemukan di sekitar anomali unsur Zn yaitu berupa serpentinit, konglomerat, batupasir, dan batugamping. Anomali unsur Zn diinterpretasikan terbentuk akibat mineralisasi epitermal dan/atau porfiri yang dikontrol oleh struktur berumur Pliosen hingga Pleistosen Tengah.

Kobalt (Co). Unsur Co memiliki nilai kandungan dengan rentang 22 ppm sampai dengan 793 ppm dan rata-rata sebesar 141 ppm, didapatkan unsur Co memiliki 
populasi anomali dengan harga ambang bernilai 324 ppm dan 407 ppm (Gambar 9). Terdapat lima titik lokasi dengan kandungan unsur Co melampaui 600 ppm yaitu MAB18508SS, MAB18531SS, MAB18510SS, MAB18509SS, dan MAB18511SS.

Titik-titik lokasi dengan kandungan Co yang besar diketahui terletak di sekitar cabangcabang Sungai Ake Fai dan Sungai Ake Sangaji. Populasi anomali unsur Co tersebar pada Komplek Batuan Ultrabasa yang didominasi oleh serpentinit di bagian barat daerah penelitian, tepatnya di sekitar hulu Sungai Ake Sangaji dan Sungai Ake Fai. Anomali unsur Co diinterpretasikan terbentuk akibat mineralisasi pengayaan supergen Ni-laterit yang terjadi pada Komplek Batuan Ultrabasa. Mineralisasi tersebut terjadi akibat pelapukan batuan serpentinit di daerah penelitian.

Nikel (Ni). Unsur $\mathrm{Ni}$ memiliki nilai kandungan dengan rentang 127 ppm sampai dengan 7.254 ppm, didapatkan unsur Ni memiliki populasi anomali dengan harga ambang bernilai 3.388 ppm (Gambar 10). Terdapat lima titik lokasi dengan kandungan unsur Ni tinggi yang melampaui 5.000 ppm yaitu MAB18526SS, MAB18528SS, MAB18522SS, MAB18508SS, dan MAB18531SS. Titiktitik lokasi dengan kandungan $\mathrm{Ni}$ yang besar diketahui terletak di sekitar cabangcabang Sungai Ake Fai, Sungai Ake Besi, dan Sungai Ake Sangaji. Populasi anomali unsur Ni tersebar pada Komplek Batuan Ultrabasa yang didominasi oleh serpentinit di bagian barat daerah penelitian. Anomali unsur Ni diinterpretasikan terbentuk akibat mineralisasi pengayaan supergen Ni-laterit yang terjadi akibat pelapukan serpentinit.

Mangan (Mn). Unsur Mn memiliki nilai kandungan dengan rentang 70 ppm sampai dengan $4.471 \mathrm{ppm}$, didapati unsur $\mathrm{Mn}$ memiliki populasi anomali dengan harga ambang bernilai 2.042 ppm dan 3.249 ppm (Gambar 11). Terdapat lima titik lokasi dengan kandungan unsur $\mathrm{Mn}$ tinggi yang melampaui $4.000 \mathrm{ppm}$ yaitu MAB18531SS, MAB18509SS,
MAB18511SS,
MAB18510SS, dan MAB18508SS. Titiktitik lokasi dengan kandungan Mn yang besar diketahui terletak di sekitar cabangcabang Sungai Ake Fai dan Sungai Ake Sangaji. Populasi anomali unsur Mn tersebar pada Komplek Batuan Ultrabasa yang didominasi oleh serpentinit di bagian barat daerah penelitian. Anomali unsur Co diinterpretasikan terbentuk akibat mineralisasi pengayaan supergen $\mathrm{Ni}-$ laterit. Mineralisasi tersebut terjadi akibat pelapukan serpentinit.

Perak (Ag). Unsur Ag memiliki nilai kandungan dengan rentang 0,1 ppm sampai dengan 3,5 ppm, didapatkan unsur Ag memiliki populasi anomali dengan harga ambang bernilai 2,2 ppm dan 2,8 ppm (Gambar 12). Terdapat dua titik lokasi dengan kandungan unsur Ag yang tinggi sebesar 2,9 ppm dan 3,5 ppm, yaitu titik MAB18504SS dan MAB18501SS di cabang Sungai Ake Nov. Populasi anomali unsur Ag tersebar pada Komplek Batuan Ultrabasa dan Formasi Tingteng. Litologi yang dapat ditemukan di sekitar anomali unsur Ag yaitu berupa serpentinit, konglomerat, batupasir, dan batugamping.

Besi (Fe). Unsur $\mathrm{Fe}$ memiliki nilai kandungan dengan rentang 1.900 ppm sampai dengan 236.800 ppm. Berdasarkan analisis univariat, didapati unsur $\mathrm{Fe}$ memiliki populasi anomali dengan harga ambang bernilai 144.500 ppm dan 183.200 ppm (Gambar 13). Terdapat dua titik lokasi dengan kandungan unsur $\mathrm{Fe}$ yang tinggi sebesar $224.500 \mathrm{ppm}$ dan $236.800 \mathrm{ppm}$ yaitu titik MAB18511SS dan MAB18508SS di cabang Sungai Ake Fai. Populasi anomali unsur Fe tersebar pada Komplek Batuan Ultrabasa yang didominasi oleh serpentinit di bagian barat daerah penelitian. Anomali unsur $\mathrm{Fe}$ diinterpretasikan terbentuk akibat mineralisasi residual. Mineralisasi tersebut terjadi akibat pelapukan batuan ultrabasa berupa serpentinit.

Krom (Cr). Unsur $\mathrm{Cr}$ memiliki nilai kandungan dengan rentang 114 ppm sampai dengan $4.663 \mathrm{ppm}$, didapatkan unsur $\mathrm{Cr}$ memiliki populasi anomali dengan 


\section{MAKALAH ILMIAH}

harga ambang bernilai $2.692 \mathrm{ppm}$ dan $3.851 \mathrm{ppm}$ (Gambar 14). Terdapat empat titik lokasi dengan kandungan unsur $\mathrm{Cr}$ tinggi yang melampaui $4.000 \mathrm{ppm}$, yaitu MAB18551SS,

MAB18597SS,

MAB18589SS, dan MAB18610SS. Titiktitik lokasi dengan kandungan $\mathrm{Cr}$ yang besar diketahui terletak di sekitar cabangcabang Sungai Tewil, Sungai Genyam, Sungai Oi, dan Sungai Ake Sigaulo. Populasi anomali unsur $\mathrm{Cr}$ tersebar pada Komplek Batuan Ultrabasa, Formasi Weda, dan Formasi Tingteng.

Anomali unsur $\mathrm{Cr}$ diinterpretasikan terbentuk akibat mineralisasi pengayaan supergen dan tidak memiliki hubungan dengan pembentukan asosiasi unsurnya. Mineralisasi tersebut terjadi akibat pelapukan batuan ultrabasa di daerah penelitian. Meskipun berasal dari mineralisasi yang serupa, namun lokasi anomali $\mathrm{Cr}$ berbeda dengan unsur $\mathrm{Ni}$, Co, dan Mn. Bila dilihat dari penyebarannya anomali Cr umumnya tersebar pada daerah yang cenderung datar, sedangkan anomali unsur $\mathrm{Ni}, \mathrm{Co}$, dan $\mathrm{Mn}$ umumnya tersebar pada daerah dengan morfologi yang relatif lebih curam.

Emas (Au). Unsur Au memiliki nilai kandungan dengan rentang 1 ppb sampai dengan $35 \mathrm{ppb}$, didapatkan unsur $\mathrm{Au}$ memiliki populasi anomali dengan harga ambang bernilai 26 ppb (Gambar 15).Terdapat dua titik lokasi dengan kandungan unsur $A u$ yang tinggi sebesar 35 ppb, yaitu titik MAB18509SS di cabang Sungai Ake Fai dan MAB18506SS di cabang Sungai Ake Volosop. Populasi anomali unsur Au tersebar pada Komplek Batuan Ultrabasa, Formasi Tingteng, serta Aluvium dan Endapan Pantai. Litologi yang dapat ditemukan di sekitar anomali unsur $\mathrm{Au}$ yaitu berupa serpentinit, konglomerat, batupasir, dan batugamping. Pembentukan anomali unsur Au memiliki genesa yang berbeda dibandingkan dengan asosiasi unsurnya.

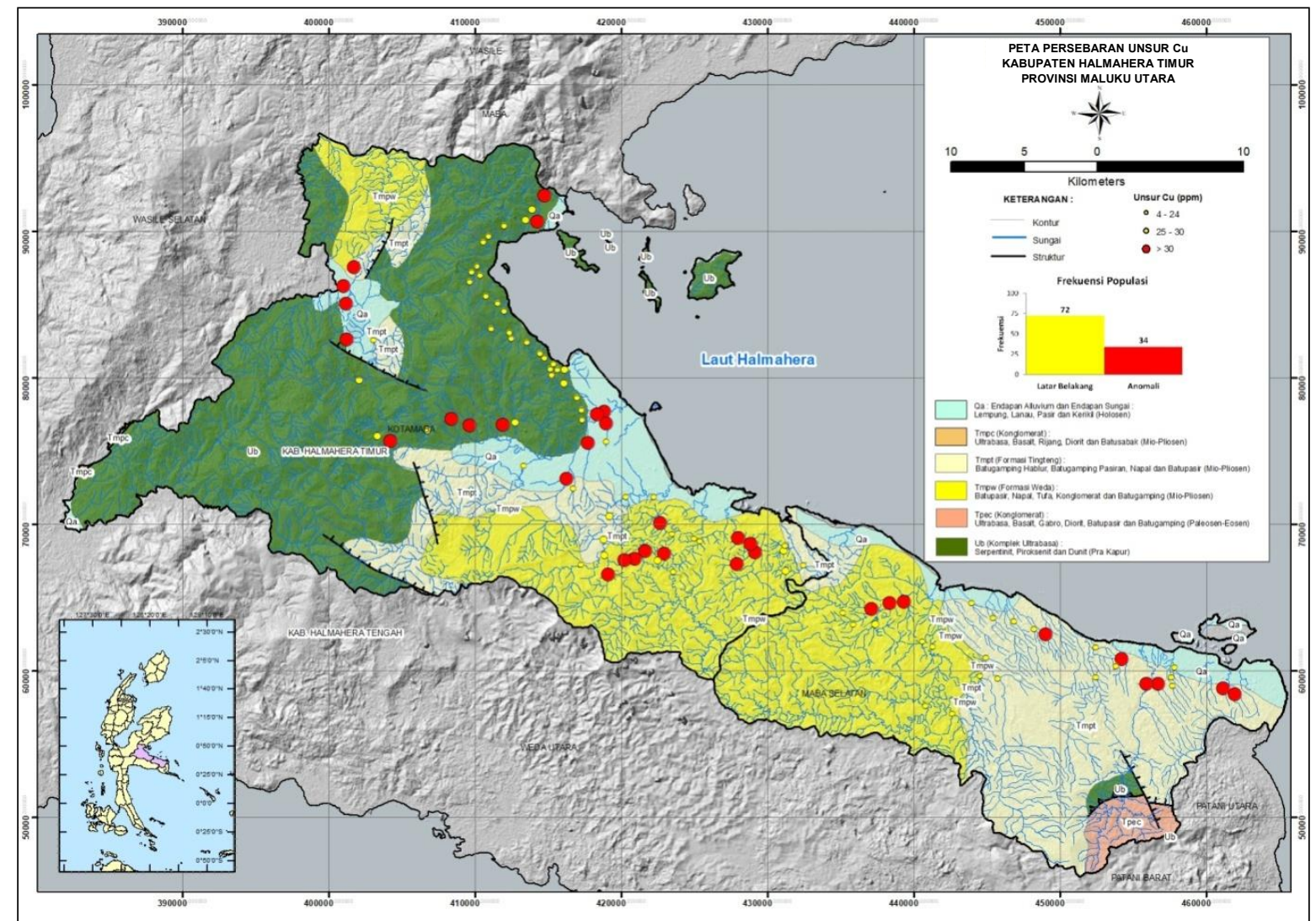

Gambar 6. Peta Persebaran Unsur Cu dalam Conto Endapan Sungai Aktif 


\section{MAKALAH ILMIAH}

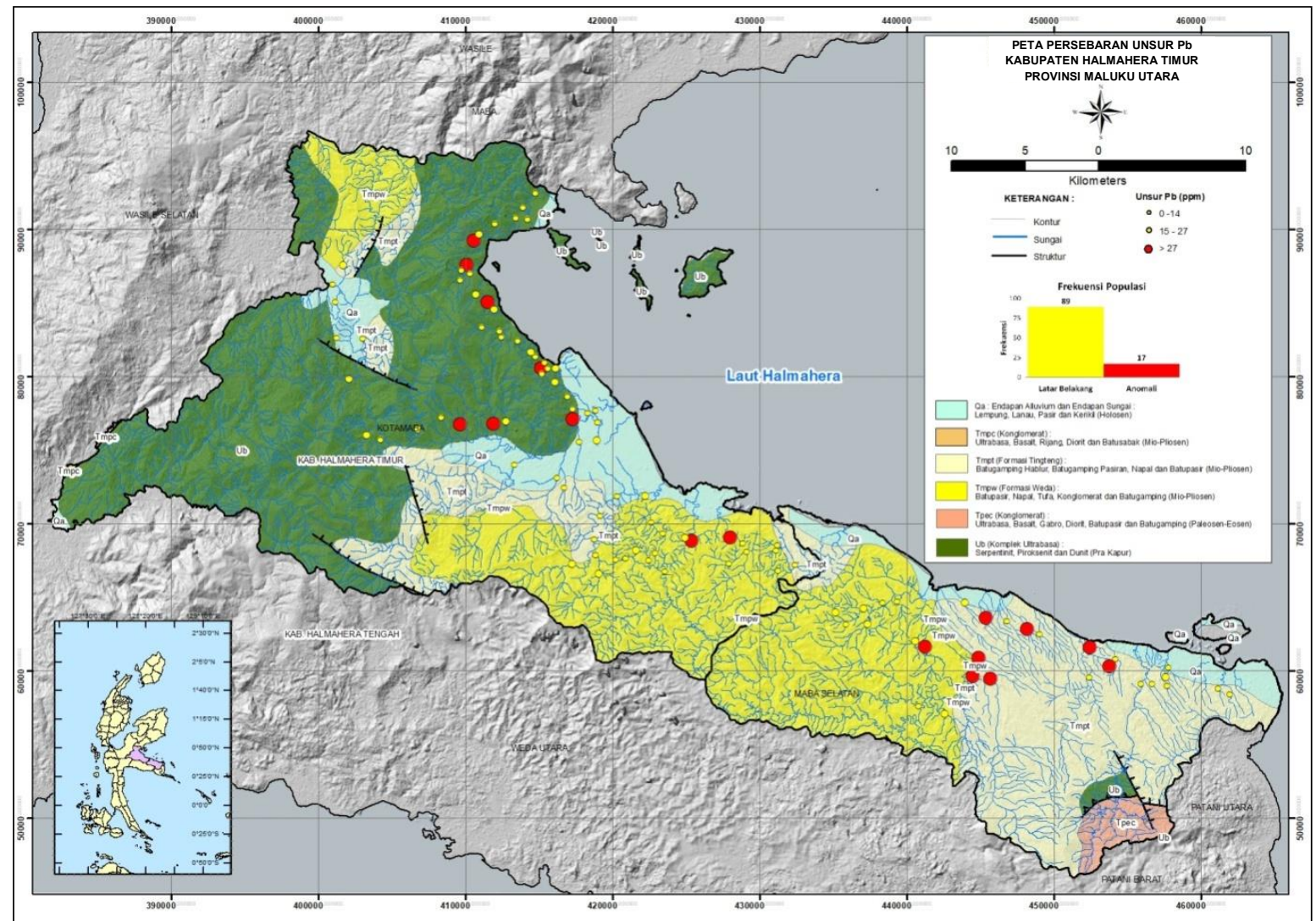

Gambar 7. Peta Persebaran Unsur Pb dalam Conto Endapan Sungai Aktif



Gambar 8. Peta Persebaran Unsur Zn dalam Conto Endapan Sungai Aktif 


\section{MAKALAH ILMIAH}

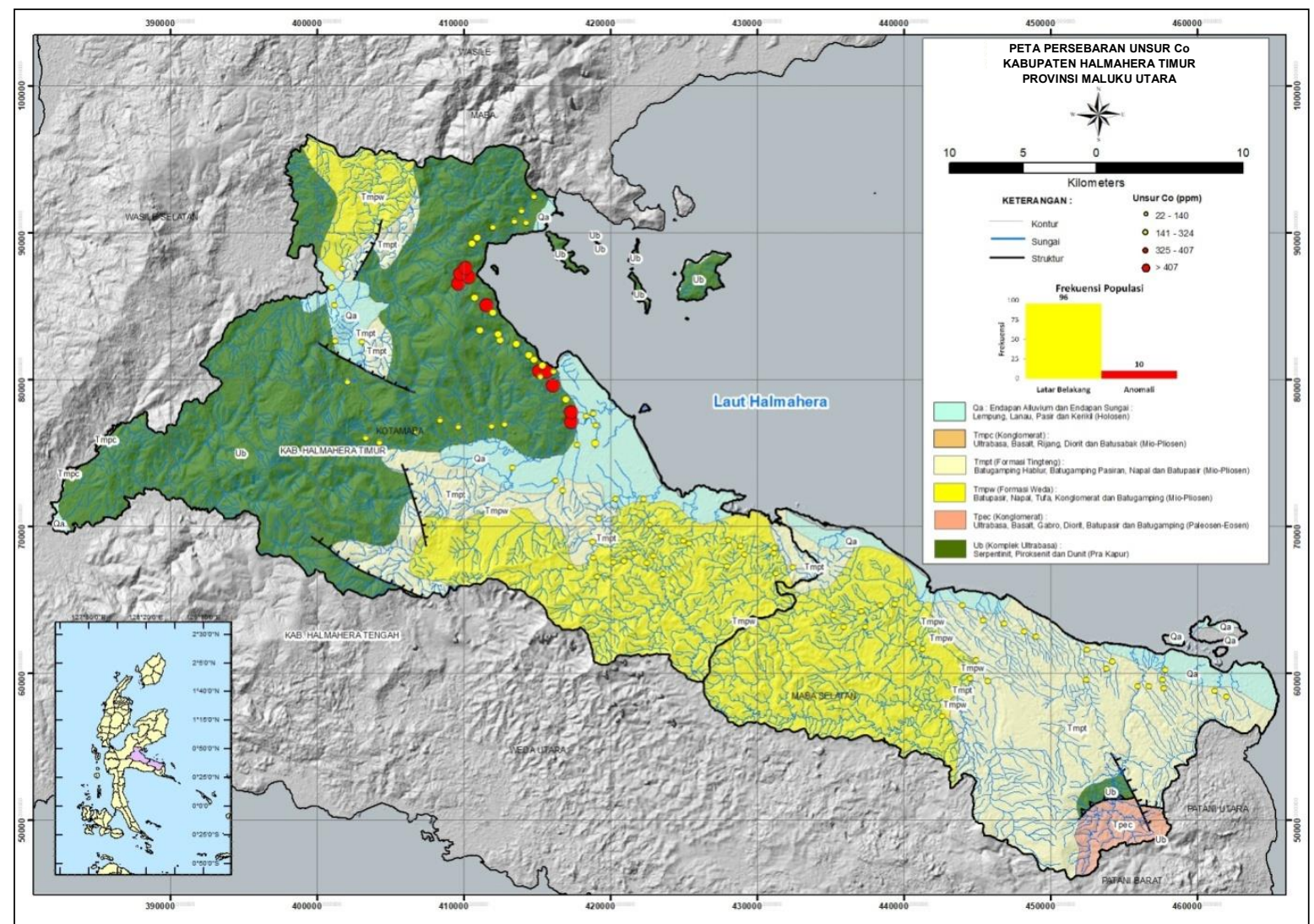

Gambar 9. Peta Persebaran Unsur Co dalam Conto Endapan Sungai Aktif

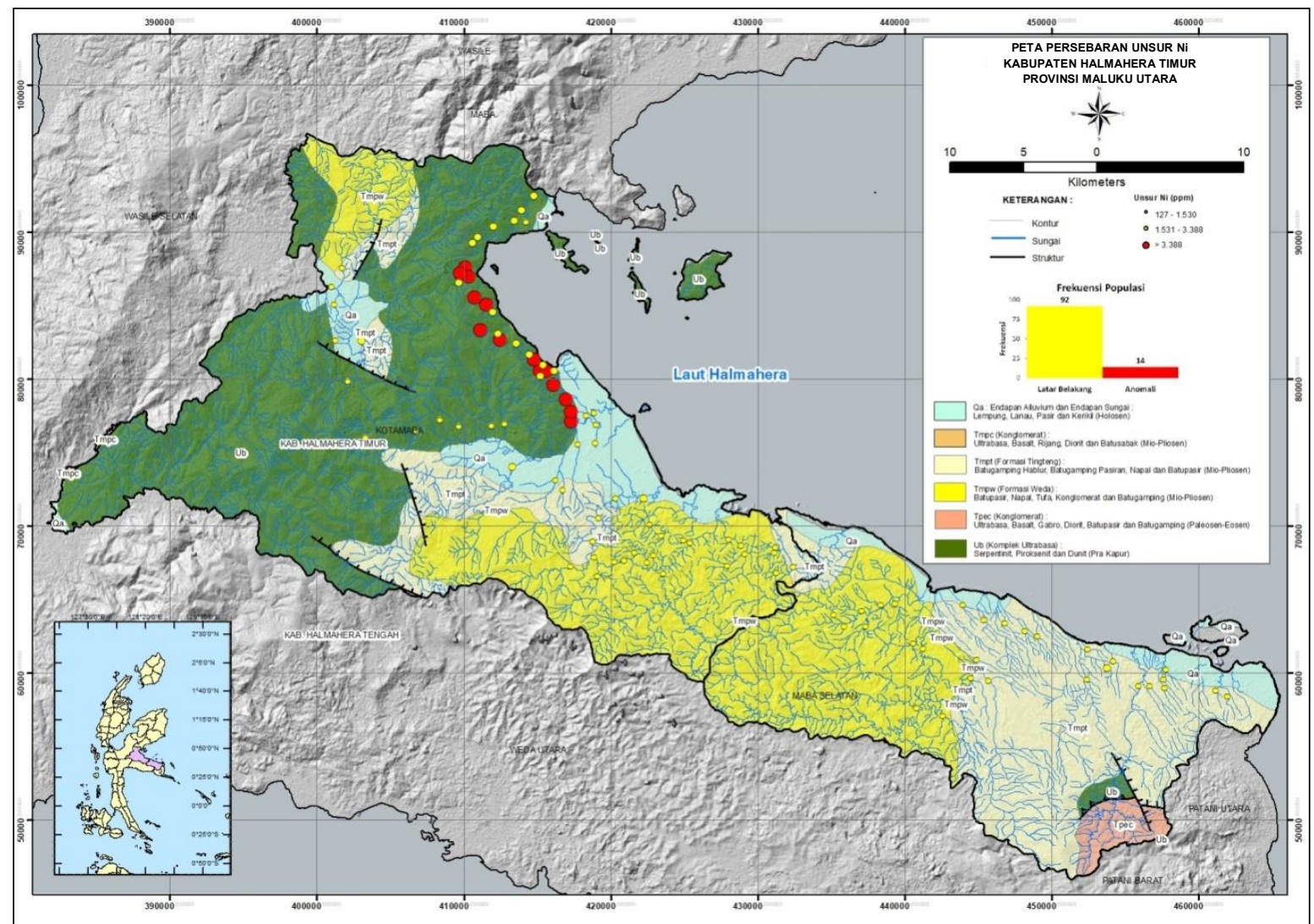

Gambar 10. Peta Persebaran Unsur Ni dalam Conto Endapan Sungai Aktif 


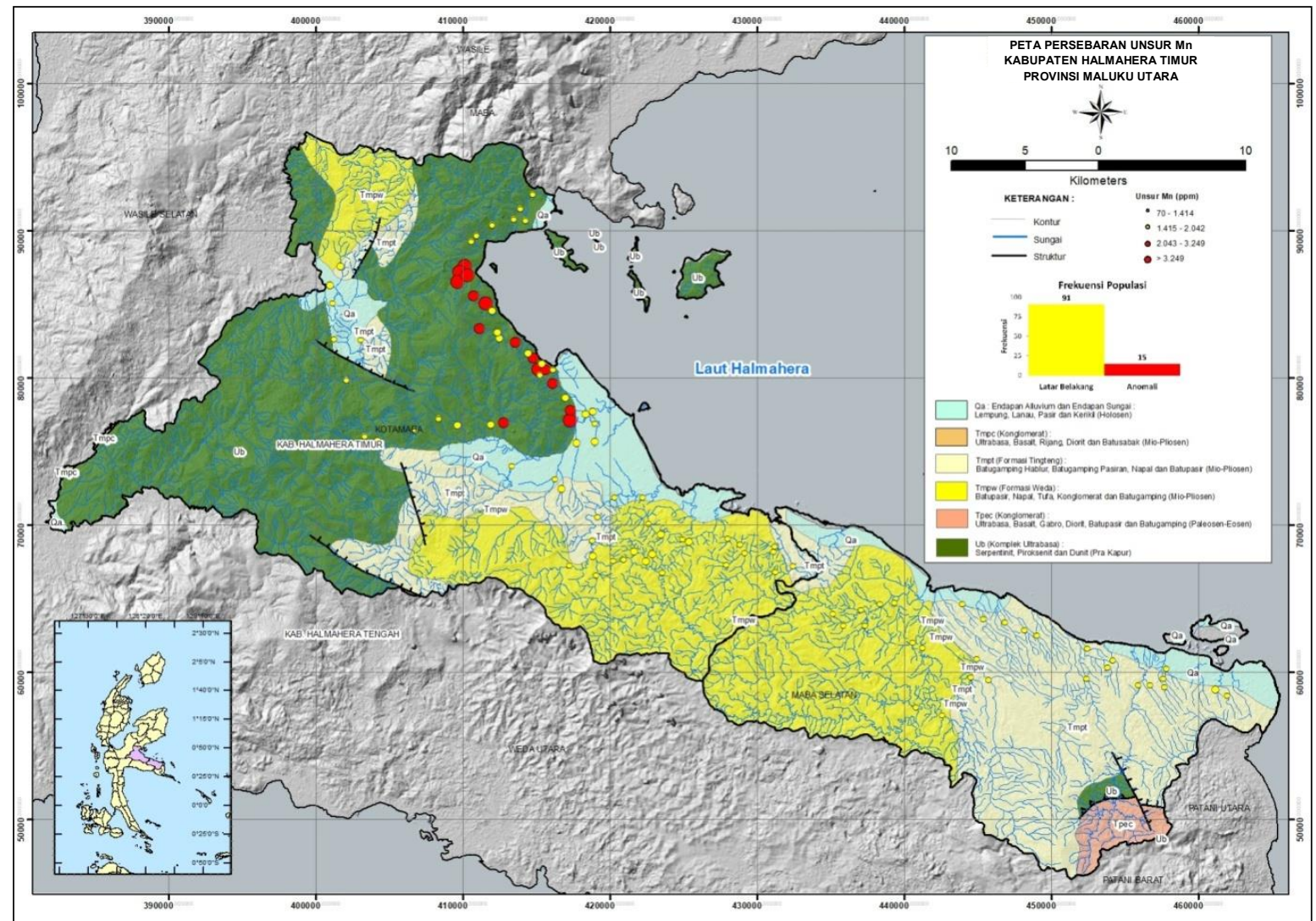

Gambar 11. Peta Persebaran Unsur Mn dalam Conto Endapan Sungai Aktif

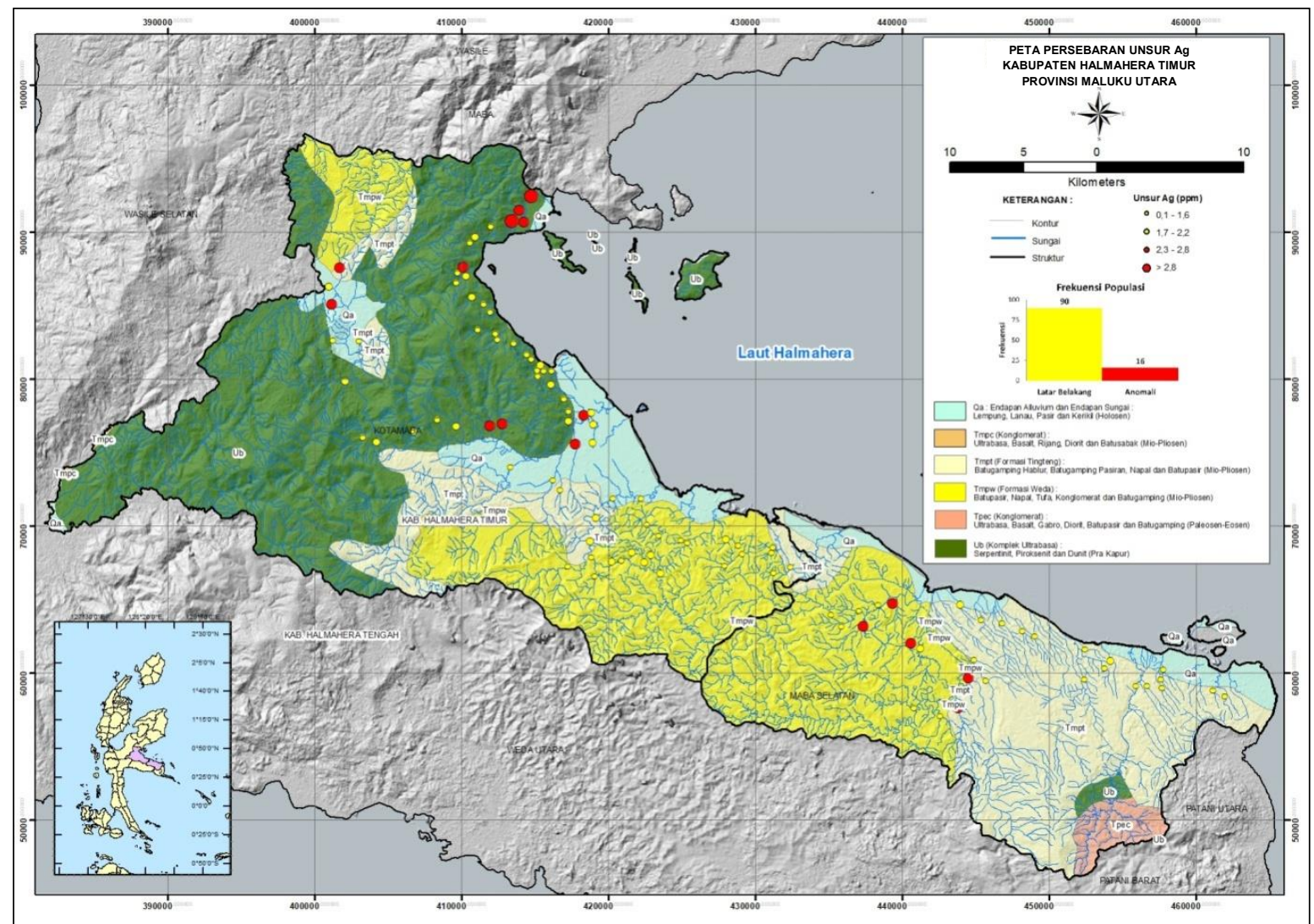

Gambar 12. Peta Persebaran Unsur Ag dalam Conto Endapan Sungai Aktif 


\section{MAKALAH ILMIAH}

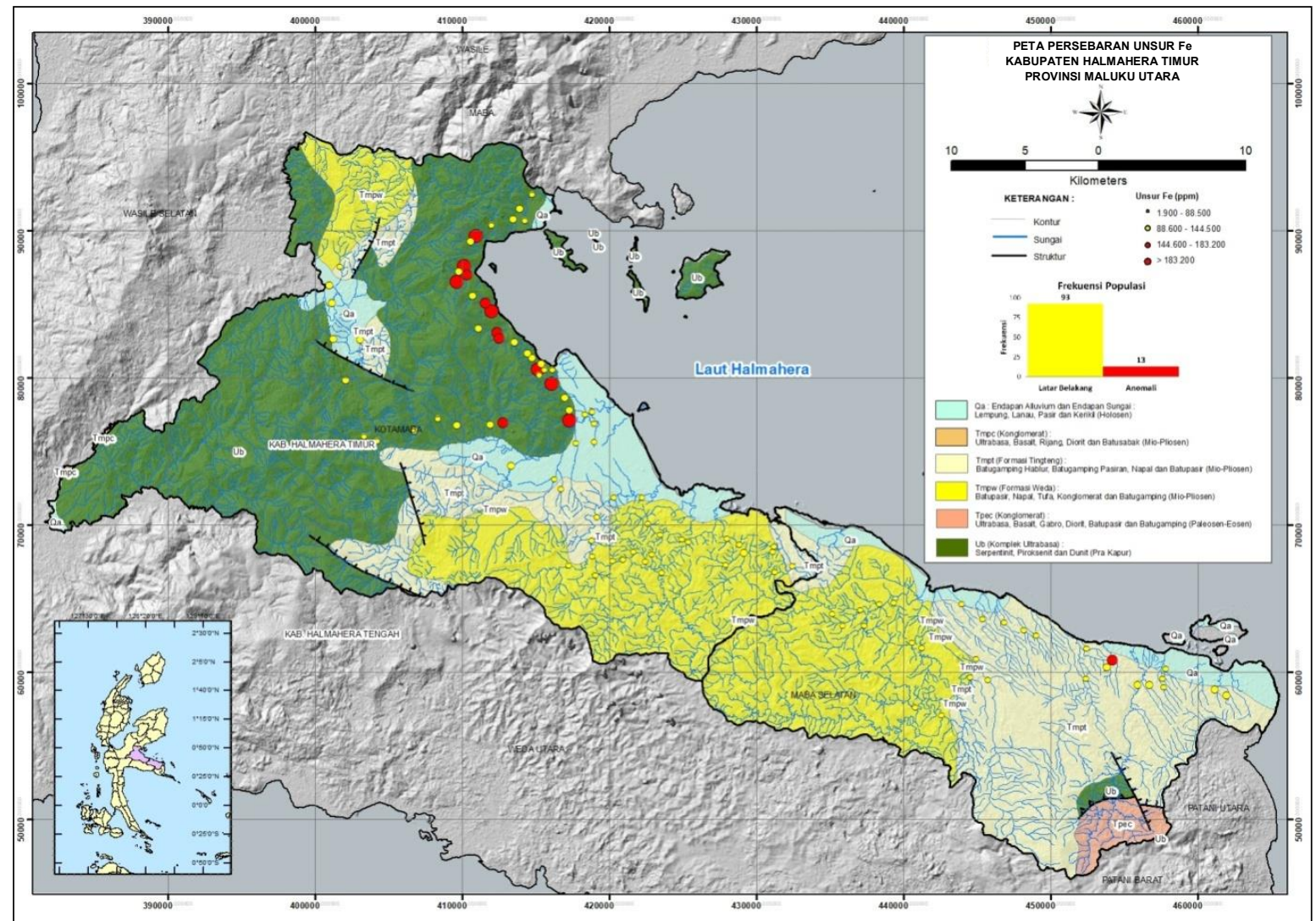

Gambar 13. Peta Persebaran Unsur Fe dalam Conto Endapan Sungai Aktif



Gambar 14. Peta Persebaran Unsur Cr dalam Conto Endapan Sungai Aktif 




Gambar 15. Peta Persebaran Unsur Au dalam Conto Endapan Sungai Aktif (WFH 15-4)

\section{ANALISIS MULTIVARIAT}

Pengolahan statistik multivariat dilakukan untuk menentukan kelompok asosiasi unsur pada daerah penelitian dengan menggunakan metode koefisien Pearson, Persentil, dan pengelompokan hierarki. Analisis multivariat dilakukan pada 106 conto sedimen sungai aktif yang terdiri dari unsur $\mathrm{Cu}, \mathrm{Pb}, \mathrm{Zn}, \mathrm{Co}, \mathrm{Ni}, \mathrm{Mn}, \mathrm{Ag}, \mathrm{Fe}, \mathrm{Cr}$, dan Au. Penentuan kelompok asosiasi unsur dilakukan dengan cara melihat hubungan dan kekerabatan antar unsur.

Menurut Ghazali dkk. (1986), metode koefisien Pearson bertujuan untuk menilai tingkat kekerabatan dari dua unsur atau lebih yang dinyatakan ke dalam koefisien Pearson (Tabel 3). Nilai koefisien berkisar dari -1 (korelasi negatif) hingga +1 (korelasi positif). Koefisien korelasi yang bernilai positif memiliki arti bahwa peningkatan nilai suatu unsur akan diikuti pula oleh peningkatan nilai unsur lain, begitu pula sebaliknya. Koefisien korelasi dengan kisaran nilai 0,5 sampai dengan 0,7 menunjukkan sifat asosiasi sedang dan koefisien dengan nilai lebih dari 0,7 menunjukkan asosiasi yang bersifat kuat (Swan dan Sandilands, 1995). Hasil di daerah penyelidikan menunjukkan adanya unsur-unsur yang berasosiasi pada persentil 80 ke atas berupa Ni-Co-Mn-FeAu dan Zn-Cu-Fe-Cr (Tabel 4).

Pengelompokan hierarki merupakan metode kluster yang mengelompokkan data secara berurutan berdasarkan kemiripan atau korelasinya (Karypis dkk., 1999). Pada metode ini setiap unsur dianggap sebagai satu variabel yang terpisah. Variabel-variabel tersebut kemudian digabungkan berdasarkan kemiripan secara berurutan hingga menjadi satu kelompok atau kluster yang besar. Penghitungan kemiripan atau jarak antar kluster dilakukan dengan metode Ward Linkage. Jarak antar kluster dihitung berdasarkan nilai error sum of square, sehingga tidak ada nilai yang saling menghilangkan. Hasil dari analisis digambarkan dengan dendogram atau diagram pohon (Gambar 16). 


\section{MAKALAH ILMIAH}

Tabel 3. Penentuan Asosiasi Unsur dengan Metode Koefisien Pearson

\begin{tabular}{|c|c|c|c|c|c|c|c|c|c|c|}
\hline Pearson & $\mathbf{N i}$ & Co & Mn & $\mathrm{Au}$ & $\mathrm{Cr}$ & Zn & $\mathbf{A g}$ & $\mathrm{Fe}$ & $\mathrm{Cu}$ & $\mathbf{P b}$ \\
\hline $\mathrm{Ni}$ & 1 & 0,9 & 0,8 & 0,4 & 0,0 & 0,3 & 0,1 & 0,0 & $-0,3$ & 0,0 \\
\hline Co & & 1 & 0,9 & 0,5 & 0,0 & 0,4 & 0,1 & 0,0 & $-0,3$ & 0,0 \\
\hline Mn & & & 1 & 0,5 & 0,0 & 0,5 & 0,2 & 0,1 & $-0,1$ & $-0,1$ \\
\hline $\mathrm{Au}$ & & & & 1 & 0,1 & 0,2 & 0,2 & 0,0 & 0,0 & $-0,1$ \\
\hline $\mathrm{Cr}$ & & & & & 1 & 0,5 & $-0,2$ & 0,1 & 0,1 & $-0,2$ \\
\hline $\mathrm{Zn}$ & & & & & & 1 & 0,0 & 0,0 & 0,3 & $-0,2$ \\
\hline $\mathrm{Ag}$ & & & & & & & 1 & 0,0 & 0,2 & 0,2 \\
\hline $\mathrm{Fe}$ & & & & & & & & 1 & 0,0 & 0,1 \\
\hline $\mathrm{Cu}$ & & & & & & & & & 1 & $-0,2$ \\
\hline $\mathbf{P b}$ & & & & & & & & & & 1 \\
\hline
\end{tabular}

Keterangan:

$r$ : nilai koefisien Pearson

$0,5 \leq r \leq 0,7 \quad$ Asosiasi Sedang

$r>0,7 \quad$ Asosiasi Kuat

Tabel 4. Penentuan Asosiasi Unsur dengan Metode Persentil

\begin{tabular}{|c|c|c|c|c|c|c|c|c|c|c|}
\hline Persentil & $\mathbf{N i}$ & Co & Mn & $\mathrm{Fe}$ & $\mathrm{Au}$ & $\mathrm{Cr}$ & $\mathrm{Zn}$ & $\mathrm{Cu}$ & $\mathbf{P b}$ & $\mathrm{Ag}$ \\
\hline $\mathbf{N i}$ & 0 & 90 & 90 & 85 & 80 & $X$ & $x$ & $x$ & $X$ & $X$ \\
\hline Co & & $\mathrm{O}$ & 90 & 90 & 80 & $x$ & $x$ & $x$ & $x$ & $X$ \\
\hline$M n$ & & & $\mathrm{O}$ & 90 & 90 & $x$ & $x$ & $x$ & $x$ & $X$ \\
\hline $\mathrm{Fe}$ & & & & $\mathrm{O}$ & 90 & $X$ & 80 & $x$ & $x$ & $X$ \\
\hline $\mathrm{Au}$ & & & & & $\mathrm{O}$ & $X$ & $X$ & $X$ & $X$ & $X$ \\
\hline $\mathrm{Cr}$ & & & & & & 0 & 80 & $x$ & $X$ & $X$ \\
\hline $\mathrm{Zn}$ & & & & & & & 0 & 85 & $X$ & $X$ \\
\hline $\mathrm{Cu}$ & & & & & & & & $\mathrm{O}$ & $x$ & $x$ \\
\hline $\mathbf{P b}$ & & & & & & & & & $\mathrm{O}$ & $X$ \\
\hline $\mathrm{Ag}$ & & & & & & & & & & $\mathrm{O}$ \\
\hline
\end{tabular}

Keterangan:

P90 Persentil 90

P85 Persentil 85

P80 Persentil 80



Gambar 16. Penentuan Asosiasi Unsur dengan Metode Pengelompokan Hierarki 
Hasil metode pengelompokkan hierarki menunjukkan terdapat adanya dua kelompok asosiasi unsur yaitu; Co-Mn-Ni$\mathrm{Fe}-\mathrm{Au}$ dan $\mathrm{Cu}-\mathrm{Ag}-\mathrm{Pb}-\mathrm{Zn}-\mathrm{Cr}$. Tingkat asosiasi antar unsur digambarkan oleh letak garis penghubung, semakin ke bawah garis penghubung antar unsur berarti semakin kuat asosiasi antara kedua unsur tersebut.

\section{HASIL DAN PEMBAHASAN}

Daerah penelitian termasuk ke dalam Mandala Halmahera Timur, yang ditempati oleh batuan beku. Pada daerah penelitian terdapat struktur sesar normal dan sesar naik dengan orientasi umum berarah utaraselatan dan baratlaut-tenggara serta struktur sinklin dan antiklin dengan sumbu lipatan berarah utara-selatan, timurlautbaratdaya, dan baratlaut-tenggara.

Berdasarkan penggabungan data hasil analisis univariat dengan hasil analisis multivariat diinterpretasikan bahwa terdapat potensi mineralisasi unsur $\mathrm{Co}-\mathrm{Ni}$ $\mathrm{Mn}-\mathrm{Fe}$. Mineralisasi tersebut memiliki hubungan dengan batuan serpentinit Komplek Batuan Ultrabasa yang mengalami pengayaan supergen akibat proses pelapukan.

Dari pengolahan data yang telah dilakukan, didapatkan daerah potensi mineralisasi yang dibatasi oleh daerah tangkapan (catchment area). Daerah potensi yang didapati berjumlah sebanyak lima lokasi, yaitu potensi Co-Ni-Mn-Fe, potensi $\mathrm{Au}$, potensi $\mathrm{Cu}-\mathrm{Pb}-\mathrm{Zn}$, potensi $\mathrm{Ag}$, dan potensi Cr (Gambar 17).

Berdasarkan penggabungan data anomali unsur univariat dengan multivariat didapatkan potensi mineralisasi dari asosiasi Co-Ni-Mn-Fe. Asosiasi unsur tersebut memiliki hubungan yang erat dengan batuan serpentinit berumur PraKapur (Komplek Batuan Ultrabasa) yang mengalami proses pengayaan supergen. Diperoleh sebanyak tiga lokasi catchment area dari potensi Co-Ni-Mn-Fe. Potensi tersebut tersebar pada titik MAB18522SS di cabang Sungai Ake Besi dengan anomali Co tertinggi 476 ppm, Ni 5.859 ppm, Mn
3.627 ppm, Fe 191.900 ppm, titik kedua MAB18508SS di cabang Sungai Ake Fai dengan anomali tertinggi Co $642 \mathrm{ppm}, \mathrm{Ni}$ 6.944 ppm, Mn 4.471 ppm, Fe 236.800 ppm, dan titik ketiga yaitu MAB18531SS di cabang Sungai Ake Sangaji dengan anomali tertinggi Co 658 ppm, Ni 7.254 ppm, Mn 4.098 ppm, Fe 186.200 ppm. Ketiga daerah potensi tersebut dikontrol oleh serpentinit dan pelapukannya, Potensi mineralisasi unsur Au di wilayah penelitian berdasarkan penggabungan data anomali unsur univariat dengan analisis multivariat, diinterpretasikan bahwa anomali unsur $\mathrm{Au}$ bersifat sekunder serta tidak memiliki hubungan yang kuat dengan litologi batuan pada daerah penelitian. Diperoleh sebanyak tiga lokasi catchment area dari potensi unsur Au. Potensi tersebut tersebar pada titik-titik berikut; titik pertama MAB18559SS di cabang Sungai Leublu dengan anomali tertinggi $30 \mathrm{ppb}$ dikontrol oleh struktur berarah baratlaut-tenggara daerah Kotamaba, titik kedua yaitu MAB18522SSdi cabang Sungai Ake Besi dengan anomali tertinggi $31 \mathrm{ppb}$ diperkirakan bersifat sekunder akibat transportasi. Titik ketiga yaitu MAB18509SS di cabang Sungai Ake Fai dengan anomali tertinggi $35 \mathrm{ppb}$ yang juga dikontrol oleh erosi dan transportasi. Dengan menelusuri hulu sungai pada titik dengan anomali tinggi unsur Au diharapkan dapat ditemukan mineralisasi yang menjadi sumber dari anomali unsur Au.

Berdasarkan penggabungan data anomali unsur univariat dengan data asosiasi unsur analisis multivariat didapatkan potensi mineralisasi dari asosiasi $\mathrm{Cu}-\mathrm{Pb}-\mathrm{Zn}$. Asosiasi unsur tersebut memiliki hubungan dengan litologi batugamping berumur Miosen-Pliosen Formasi Tingteng dan litologi batupasir berumur Miosen-Pliosen Formasi Weda. Diperoleh sebanyak dua lokasi catchment area dari potensi Co-NiMn-Fe. Potensi tersebut tersebar pada titik MAB18605SS di cabang Sungai Pagah dengan anomali tertinggi $\mathrm{Cu} 45 \mathrm{ppm}, \mathrm{Pb} 14$ ppm, Zn 103 ppm, dan titik kedua MAB18563SS di cabang Sungai Piyoy dengan anomali tertinggi $\mathrm{Cu} 33 \mathrm{ppm}, \mathrm{Pb} 40$ ppm, Zn 111 ppm. Kedua daerah potensi 


\section{MAKALAH ILMIAH}

tersebut ditemukan pada lokasi dengan litologi berupa batuan sedimen, diperkirakan bahwa sumber anomali unsur asosiasi $\mathrm{Cu}-\mathrm{Pb}-\mathrm{Zn}$ berasal dari mineralisasi yang berada di hulu sungai.

Potensi mineralisasi unsur Ag di wilayah penelitian berdasarkan penggabungan data anomali unsur univariat dengan analisis multivariat, diinterpretasikan bahwa anomali unsur Ag tidak memiliki hubungan yang kuat dengan litologi daerah penelitian. Diperoleh sebanyak empat lokasi catchment area dari potensi unsur Ag. Potensi tersebut tersebar pada titik-titik berikut; titik pertama MAB18579SS di cabang Sungai Ake Won dengan anomali tertinggi 2,5 ppm dikontrol oleh erosi dan transportasi, titik kedua yaitu MAB18564SS di cabang Sungai Ake Po dengan anomali tertinggi 2,5 ppm, titik ketiga yaitu MAB18552SS di cabang Sungai Ake Polno dengan anomali tertinggi 2,8 ppm dikontrol oleh struktur berarah baratlaut-tenggara daerah Kotamaba, titik keempat yaitu MAB18501SS di cabang Sungai Ake Nov dengan anomali tertinggi 3,5 ppm dikontrol oleh erosi dan transportasi. Dengan menelusuri hulu sungai pada titik dengan anomali tinggi unsur Ag diharapkan dapat ditemukan mineralisasi yang menjadi sumber dari anomali unsur Ag.

Potensi mineralisasi unsur $\mathrm{Cr}$ di wilayah penelitian berdasarkan penggabungan data anomali unsur univariat dengan analisis multivariat, diinterpretasikan bahwa anomali unsur $\mathrm{Cr}$ memiliki hubungan yang kuat dengan batuan serpentinit berumur Pra-Kapur Komplek Batuan Ultrabasa pada daerah penelitian. Diperoleh sebanyak tiga lokasi catchment area dari potensi unsur $\mathrm{Cr}$. Potensi tersebut tersebar pada titik-titik berikut; titik pertama MAB18551SS di cabang Sungai Tewil dengan anomali tertinggi $4.163 \mathrm{ppm}$, titik kedua yaitu MAB18597SS di cabang Sungai Ake Genyam dengan anomali tertinggi $4.279 \mathrm{ppm}$, titik ketiga yaitu MAB18561SS di cabang Sungai Balipopo dengan anomali tertinggi $4.663 \mathrm{ppm}$. Anomali unsur $\mathrm{Cr}$ dikontrol oleh pelapukan batuan dasar serpentinit yang memicu proses pengayaan supergen.



Gambar 17. Peta Persebaran Daerah Potensi Co-Ni-Mn-Fe, potensi Au, potensi $\mathrm{Cu}-\mathrm{Pb}-\mathrm{Zn}$, potensi $\mathrm{Ag}$, dan potensi $\mathrm{Cr}$ dalam Conto Endapan Sungai Aktif 


\section{KESIMPULAN DAN SARAN}

Analisis anomali geokimia sedimen sungai di Halmahera Bagian Timur terhadap unsur $\mathrm{Cu}, \mathrm{Pb}, \mathrm{Zn}, \mathrm{Co}, \mathrm{Ni}, \mathrm{Mn}, \mathrm{Ag}, \mathrm{Fe}, \mathrm{Cr}$, dan $\mathrm{Au}$ diperoleh data indikasi mineral logam berdasarkan hasil analisis data sebagai berikut:

\section{Analisis Univariat}

Dari integrasi data diperoleh indikasi potensi mineralisasi di 15 lokasi, yaitu: Potensi asosiasi unsur Co-Ni-Mn-Fe (Co 324 sampai dengan 793 ppm, Ni 3.388 sampai dengan $7.254 \mathrm{ppm}, \mathrm{Mn} 2.042$ sampai dengan $4.471 \mathrm{ppm}$, Fe 144.500 sampai dengan $236.800 \mathrm{ppm}$ ) diperoleh tiga daerah potensi yaitu Ake Besi, Ake Fai, dan Ake Sangaji. Potensi unsur Au (26 sampai dengan $35 \mathrm{ppb}$ ) diperoleh tiga daerah potensi yaitu Leublu, Ake Besi, dan Ake Fai. Potensi $\mathrm{Cu}-\mathrm{Pb}-\mathrm{Zn}$ (Cu 30 sampai dengan 47 ppm, Pb 27 sampai dengan 90 ppm, Zn 93 sampai dengan 142 ppm) diperoleh dua daerah potensi yaitu Pagah dan Piyoy. Potensi Ag (2,2 sampai dengan 3,5 ppm) diperoleh empat daerah potensi yaitu Ake Won, Ake Po, Ake Polno, dan Ake Nov. Potensi Cr (2.692 sampai dengan 4.663 ppm) diperoleh tiga daerah potensi, yaitu Tewil, Ake Genyam, dan Balipopo.

\section{Analisis Multivariat}

Dari integrasi data hasil analisis anomali geokimia dan pola sebaran anomali unsur $\mathrm{Cu}, \mathrm{Pb}, \mathrm{Zn}, \mathrm{Co}, \mathrm{Ni}, \mathrm{Mn}, \mathrm{Ag}, \mathrm{Fe}, \mathrm{Cr}$, dan $\mathrm{Au}$ yang dihubungkan dengan kekerabatan atau hubungan antar unsur dari unsurunsur tersebut, diperoleh dua kelompok unsur yaitu ikatan unsur $\mathrm{Cu}-\mathrm{Pb}-\mathrm{Zn}-\mathrm{Ag}-\mathrm{Cr}$ dan Co-Ni-Mn-Fe-Au, akan tetapi tidak semua kelompok asosiasi unsur dapat dihubungkan dengan litologi daerah penelitian.

\section{UCAPAN TERIMA KASIH}

Pada kesempatan ini penulis mengucapkan terima kasih kepada anggota tim lapangan, teknisi, dan penganalisis laboratorium yang membantu kelancaran kerja hingga selesai.

\section{DAFTAR PUSTAKA}

Apandi, T. dan Sudana, D., 1980, Peta Geologi Lembar Ternate, Maluku Utara Skala 1 : 250.000. Pusat Penelitian dan Pengembangan Geologi, Bandung, Direktorat Jendral Geologi dan Sumberdaya Mineral, Departemen Pertambangan dan Energi.

Fadhly, A., Syafri, I., dan Abdurrokhim, 2017, Zonasi anomali unsur geokimia di Weda, Kabupaten Halmahera Tengah, Maluku Utara berdasarkan data univariat dan multivariat, Bulletin of Scientific Contribution, Volume 15, Nomor 3, hlm. 243-254.

Faisal, R., Soepriadi, Rosana, M., dan Yuningsih, E., 2015, Analisis Faktor dan Univariat Dalam Penentuan Potensi Mineralisasi $\mathrm{Cu}, \mathrm{Pb}, \mathrm{Zn}$ di Halmahera Bagian Barat, Maluku Utara, Buletin Sumber Daya Geologi, Volume 10 Nomor 3, halaman 167183.

Faisal, R., dan Mauritz, J., 2018, Survei Geokimia Regional Bersistem Lembar Ternate A-5, Pulau Halmahera, Provinsi Maluku Utara. Pusat Sumber Daya Mineral Batubara dan Panas Bumi, Badan Geologi, Kementerian Energi dan Sumber Daya Mineral.

Ghazali, S. A., Muchjidin, dan Hariwidjaja, 1986, Penyelidikan Geokimia Endapan Sungai: Metode dan Teknik. Direktorat Sumber Daya Mineral, Bandung. 


\section{MAKALAH ILMIAH}

Karypis, G., Han, E., dan Kumar, V.,1999, Chameleon: hierarchical clustering using dynamic modeling. IEEE Computer, Vol. 32, Issue 8, Aug 1999.

Levinson, A. A., 1980, Introduction to Exploration Geochemistry. Edisi Kedua. Applied Publishing, Illinois.
Rose, A. W., Hawkes, H. E., dan Webb, J. S., 1979, Geochemistry in Mineral Exploration. Edisi Kedua. Academic Press, London.

Surjadi, P. A., 1976, Pendahuluan Teori Kemungkinan dan Statistika. Penerbit ITB, Bandung.

Swan, A. R. H. and Sandilands, M., 1995, Introduction to Geological Data Analysis, Blackwell Science Ltd., Oxford.

\begin{tabular}{|ll|}
\hline Diterima & $:$ 13 Agustus 2019 \\
Direvisi & $:$ 3 Desember 2019 \\
Disetujui & $: 6$ Mei 2020
\end{tabular}

